\title{
THE MAKING OF LANGUAGES AND NEW LITERACIES: SAN ANDRÉS-PROVIDENCE CREOLE WITH A VIEW ON JAMAICAN AND HAITIAN
}

\author{
Angela Bartens \\ University of Turku (Finland) \\ angbar@utu.fi \\ Received: 18/02/2020 - Approved: 28/07/2020 - Published: 15/04/2021 \\ DOI: doi.org/10.17533/udea.lyl.n79a13
}

\begin{abstract}
The aim of this paper is to examine the idea of «language making» and new literacies in creole languages with a focus on San Andrés-Providence Creole English. Jamaican and Haitian Creole are taken as points of comparison for their more advanced state of consolidation. Posts from Facebook groups gathered between February 2016 and July 2020 as the main source of data were complemented by 2015 data on San Andrés linguistic landscapes. The main finding is that, due to a favorable change in language attitudes both locally and globally, San Andrés-Providence Creole is entering into the domain of writing.
\end{abstract}

Key words: Creole languages; San Andrés-Providence Creole English; language making; new literacies.

\section{LA CREACIÓN DE LENGUAS Y LECTOESCRITURAS NUEVAS: EL CRIOLLO DE SAN ANDRÉS Y PROVIDENCIA CON UNA MIRADA HACIA EL JAMAIQUINO Y EL HAITIANO}

Resumen: Se examina la idea de «creación de lenguas» y lectoescrituras en lenguas criollas con un enfoque en el criollo de San Andrés y Providencia. El criollo jamaiquino y haitiano se toman como puntos de comparación por su mayor prestigio. La principal fuente de datos la constituyen publicaciones de grupos de Facebook, recogidas entre febrero de 2016 y julio de 2020, así como imágenes de paisajes lingüísticos sanandresanos de 2015. El hallazgo principal es que, debido a un cambio positivo en las actitudes lingüísticas, tanto a nivel local como global, el criollo sanandresano-providenciano está entrando en el dominio de la escritura.

Palabras clave: lenguas criollas; criollo inglés de San Andrés y Providencia; creación de lenguas; nuevas lectoescrituras. 


\section{Introduction}

I n this paper, the concept of «language making» (Makoni \& Pennycock, 2005; Hüning \& Krämer, 2018) and new literacies in creole languages are being examined. The focus is on San Andrés-Providence Creole English (henceforward CE) ${ }^{1}$ which the researcher has done fieldwork on in situ. A comparison is made with Jamaican $\mathrm{CE}$ - which has been historically important for the emergence of and as a point of reference for the San Andrés-Providence CE community - as well as Haitian Creole. In this endeavor, the new media including Facebook (FB) and FB groups provide easily accessible material for studying language use, emergent norms, and ideologies with regard to language making and new literacies. Posts from FB, especially FB groups, gathered between February 2016 and July 2020 constitute the main source of data for this study. In addition, use is made of previous work by the same author and data gathered on San Andrés linguistic landscapes (a total of 378 pictures from mainly urban areas) in October 2015. All the data was analyzed qualitatively for the categories named as «content» and «language choice» — cf. Schreier et al. (2019) for Qualitative Content Analysis—. In this paper, examples of the data gathered will be given and do not aim at a quantitative appraisal of it. ${ }^{2}$

Considering the continuum orality-literacy, new technology enables minority languages to enter, so to speak, «through the back door» into the domain of literacy, crucial for eventual H (high) language status (Ferguson, 1959). This results in the decolonization of the traditional power relationships between $\mathrm{H}$ (high) and L (low) varieties (Ferguson, 1959) and the «democratization of former elite practices» (Mair, 2019) as the world's most peripheral and endangered languages benefit from the opportunities offered by the internet (Eisenlohr, 2004).

In the ideal case, it would be possible to show that the use of minority languages such as San Andrés-Providence $\mathrm{CE}$ on FB either reflects or may spill over to «traditional» media as language ideologies evolve. It is too early to predict the ultimate outcome of the positive change in attitude, but the development which can be observed seems very promising. In fact, a radical change in favor of minority language use has occurred over the past twenty years not only in this community but on a global scale as shall be argued below. In the case of writing and literacy, an interesting point of comparison — albeit not from «traditional» media — is constituted by the use and making of languages in the linguistic landscapes of bi-/trilingual communities (Landry \& Bourhis, 1997), the data coming, as mentioned above, from the San Andrés community.

\footnotetext{
1. San Andrés, (Old) Providence and St. Catherine make up the Colombian department of San Andrés. Saint Catherine is a small island separated from Providence by a narrow channel. The location of the archipelago is $12-16^{\circ} \mathrm{N}, 78-82^{\circ} \mathrm{W}$. The superficies of the islands are as follows: San Andrés $25 \mathrm{~km}^{2}$, Old Providence $19 \mathrm{~km}^{2}$, Saint Catherine $1 \mathrm{~km}^{2}$, total including the keys: $52,05 \mathrm{~km}^{2}$. San Andrés is a coral reef with relatively smooth hills in the center. Old Providence and Saint Catherine are of volcanic in origin. See below for an explanation for the term San Andrés-Providence CE.
}

2. See subsection 3.3. for some difficulties encountered with quantitatively studying posts in FB groups. 


\section{Language Ideologies and Challenges in the Present-Day Making of Creole Languages}

For the purposes of argumentation, it seems useful to give a definition of a Creole language: ${ }^{3}$

A creole language is a language that has arisen from a language contact situation where speakers of a multitude of languages had to acquire a Means of Interethnic Communication (MIC; Baker, 1990). It is a language that is capable of fulfilling all the linguistic functions of the relevant speech community. Frequently, but not always, these speakers were socially subjugated by a small elite. Creoles usually have one lexifier language, i.e., they derive the bulk of their lexicon from one language, whereas the other levels of the language structure are a result of complex processes that creolists are still trying to understand and describe in full (Bartens, 2013, p. 65).

That a language can fulfill all linguistic functions is an obvious point, to be found in the thinking of many scholars and language planners, e.g., Eliezer Ben-Yehuda (Coulmas, 2016), but relevant for the present purposes. This, however, leads to the question: What exactly is a language? In order to define a language in general, ideologies need to be discussed first.

Ideologies are social representations of the fundamental beliefs shared by a group or movement. They constitute the basis of the group's collective memory, norms and values — including language attitudes - and a frame of reference for interpreting the world. They translate into the practices of its members and their disposition to assimilate knowledge and can therefore also be considered a form of collective self-representation (van Dijk, 2003). They are manifest in, for instance, self-glossonyms and other self-denominations as well as diverse discourses. In the San Andrés-Providence community mainly studied here, these discourses include discourses on «language as a problem» (Bartens, 2018, p. 400), an expression of linguistic insecurity as the dilemma between overt vs. covert prestige which can be found in probably every creole community, no matter to what extent standardization has advanced (Labov 1972; Rickford, 1985; Edwards, 1968).

Bearing this in mind, I now turn to what constitutes a language. Lay people insist on the idea that the distinction between a language and a dialect lies in interlinguistic differences: " "If I understand you, you must be speaking the same language as I do. Or is a language a dialect with an army and a navy" (famous utterance attributed to Max Weinreich) or even a flag? » Rosen (1994, cited in McArthur, 1998, p. 205) attributes the change of the navy to a flag to Randolph Quirk, thus emphasizing the link established at least since German Romanticism between a nation/nation state, its culture, and language as an expression of the Volksgeist, according to Herder (1772). Crystal (1998) expressed the same idea in the following terms:

$[\ldots]$ to promote an autonomous language policy, two criteria need to be satisfied. The first is to have a community with a single mind about the matter, and the second is to have a community which has enough political-economic «clout» to make its decision respected by outsiders with whom it is in regular contact (pp. 85-86).

Sociopolitical factors are indeed paramount, but speakers' perceptions (Preston, 2014) should not be neglected, either. The result tends to be the intertwining or interaction of both stances. In addition, a language —as opposed to a dialect - is supposed to have certain attributes: an orthography, a linguistic standard defined in and by

3. In the original, italics are used only for «Means of Interethnic Communication», commonly abbreviated MIC in the literature. The second passage is italicized here in order to stress the point relevant for this paper. 
The Making of Languages and New Literacies: San Andrés-Providence Creole with a View on Jamaican and Haitian reference works, a literary canon, etc.

Here hitherto — nearly — languages with no graphemes face special challenges. The creation and ratification of orthographies is a first, but enormously important milestone despite the fact that new technologies allow for the revision of web-based materials in a manner which was unthinkable of when the dissemination of the results of corpus planning depended almost entirely on book printing. The observation made by Crystal (2000, p. 141) that a minority language can be maintained «if its speakers can make use of electronic technology» can be extended to all promoters of the language and the creation of materials. ${ }^{4}$

In the creation of orthographies, linguists recommend the maximization of the phoneme-grapheme correspondence. In the case of a language like San Andrés-Providence CE — and closely related Nicaraguan CE, see below_-, speakers have tended to reject such proposals as «looking too much like Spanish», the orthography of which is much more phonematic than the English one. Adherence to lexifier language standards, i.e., an etymologizing orthography —or «historical-etymological» in the taxonomy of Winer (1990) —, is advocated by those who have had the privilege of acquiring literacy in the lexifier language, e.g., teachers, or, for instance, parents who aim at providing their children with a better future, the traditional argument being that literacy in creole languages should enable a smooth transition to literacy in the lexifier language (Bartens, 2001, p. 30).

Interestingly, even considering a small number of graphemes, $\{\mathrm{k}, \mathrm{w}, \mathrm{y}\}$, these have led to heated debates. Leaving $\{\mathrm{k}\}$ aside, foreign to Romance languages and thence disputed and associated with certain political ideologies, more specifically communism, in Romance-lexifier creoles (Bartens, 2001, p. 30), $\{\mathrm{w}\}$ and $\{\mathrm{y}\}$ have provoked opposing reactions, again due to the fact whether these graphemes are part of the lexifier language orthography or not. In the painstaking process towards the establishing of an orthography for Haitian Creole, $\{\mathrm{w}\}$ and $\{y\}$, when proposed as part of the so-called McConnell-Laubach orthography (1940/1943), were rejected by educated Haitians, including Pressoir (1947), «because of its Association with Protestantism and its "American" look» (Schieffelin \& Doucet, 1994, p. 184). As far as San Andrés-Providence CE is concerned, where «a tenuous, almost mythicized presence» of Standard English as a H language can be observed (Freeland, 2004, p. 111, on closely related Nicaraguan $\mathrm{CE}),\{\mathrm{w}\}$ and $\{\mathrm{y}\}$ have been recommended especially in word-final position for «looking better»: \{kow\} ['kov] «cow», \{sity\} ['siti] «city». In the words of Schieffelin \& Doucet (1994) traditional media contributes to transform languages this way:

When a language is codified and an orthography is officially adopted, this is usually interpreted to mean that there is one correct way to spell and write the language, and that all others are simply wrong. [...] And when a variety through its officialization is given the status of a standard, the users of the other varieties sometimes react with surprising virulence because they feel that their language variety and its speakers are denied representation (pp. 192-193).

This is part and parcel of any language standardization process. A sensible compromise solution is to allow for an initial phase of variation in standardization — see Koskinen (2010), on Nicaraguan CE speaks of «normalization» and Sorba (2019), on similar ideas with regard to Corsican-.

4. The question of language ownership, relevant for minority language revitalization and maintenance is briefly alluded to in section 4 . 
The Making of Languages and New Literacies: San Andrés-Providence Creole with a View on Jamaican and Haitian

The presumably high cost of producing reference works such as grammars, dictionaries, etc., and teaching materials as part of corpus planning is rendered every time lower due to the advances in information technology (IT). The essential tools needed are a computer, possibly a printer, and knowhow — both technical and with regard to contents - to produce materials such as the Big Books used in the trilingual pilot project executed in three San Andrés schools over the years 1999-2004 (Morren, 2010). Another essential attribute of a «language», its literary canon, presents challenges as well. At times writers start their career writing in creole, then turning to more lucrative publishing in the $\mathrm{H}$ language of the community. Translated works, e.g., French classics into Haitian Creole or Portuguese theater into Kabuverdianu — see Lopes (2017), for the second case_-, constitute a viable solution.

Considering Western ideologies and despite postcolonial thinking — $c f$. Freeland (2004) on Nicaraguan Creole_- not writing is not an option: «A language starts to exist once it is written» (Lüpke, 2018, p. 141). In other contexts, it is preferred the less political «varieties». In the case of minorized varieties, however, it is of utmost importance to speak of languages. But it is possible to start with different formats of writing. After discussing the idea of language making, the different modes of writing will be discussed below.

When defining a language, it is possible to evoke historical cases of language making, e.g., Finnish, which was created from the 16th century onwards (Lehikoinen \& Kiuru, 1991, pp. 2, 12). Sociopolitical —and sociocultural - factors play a crucial role as stated above. Is the community ready to embrace the promotion of language standardization? At times, conscientization and subsequent action is facilitated by distinct, overlapping mechanisms, for example, both grassroots and institutional support, which can also be international, a case in point being constituted by Mirandês, a variety of Leonese — an Iberoromance language of North Western Spainspoken in Miranda do Douro (Portugal), which has benefited from both national and international institutional support since 1986 - by the Ministry of Education of Portugal, the City Council of Miranda do Douro, the universities of Lisbon, Coimbra, and Porto, and the European Community — . This may lead to a consolidation of the debate on language policy. New technologies play a crucial part in this process as argued below.

Are we dealing with a global tendency of language making? Or is it the disinvention and subsequent reconstitution (Makoni \& Pennycock, 2005) of what we generally conceive of as language? In cases of longstanding stigmatization and minorization of linguistic varieties, clear-cut boundaries, labels, names and norms are required (Hüning \& Krämer, 2018; Grimm, 1864) in the making of a language for both speakers and others to conceive of a variety as one. 


\section{Language Making and New Literacies: San Andrés-Providence, Jamaican, and Haitian Creole}

As stated above, the focus is on San Andrés-Providence CE. Jamaican and Haitian are cited as cases it is possible to make comparisons with, e.g., for much more advanced use of them in the new media. ${ }^{5}$ Firstly, it is important to situate San Andrés-Providence CE in its sociohistorical context and present its contemporary sociolinguistic situation. Then, an overview of language use on FB as a manifestation and test ground for new literacies will be provided. Finally, a brief comment on language making in the linguistic landscape of San Andrés will be made.

\subsection{Social History of San Andrés and Old Providence}

The islands were first colonized by English Puritans in 1627/1631-1641, ${ }^{6}$ but the foundations of the actual population were laid ca. 1730 with the arrival of colonists from other parts of the British Caribbean, especially Jamaica, and directly from the British Isles - above all from Scotland and Ireland - . In this context, it is important to stress the central role of slave importations through Jamaica, leading to an Akan - Western Kwa, especially Twi-Fante - bias in the substrate, albeit not of immediate concern for the purposes of this paper. It is a secondgeneration creole pace Chaudenson (1992) which probably jelled during the second half of the 18th century (Bartens, 2009).

However, trade contacts and back and forth migrations between the insular Caribbean and the Central American Coast from the first half of the 17th century until the early 20th century has led to a state of affair where the genetic relationships and direction of transfer between the closely related English-lexifier creoles of the region - all outcomes of the colonial enterprise of England/Britain — have become obscured. As a result, there is a high degree of similarity and mutual intelligibility between them, constituting an undeniable potential for language development. Traditionally, Jamaica has constituted a cultural point of reference, but at present further information and experiences in language development are exchanged throughout the region.

The sociolinguistic setting of San Andrés-Providence CE has been defined by forced Hispanization and Catholicization between 1902 and 1926, as well as throughout the 20th century, only partially halted since the early 1990s: The present Colombian Constitution was ratified in 1991, granting the Department of San Andrés and Providence a special status as elaborated in Act 47 of 1993. On linguistic terms, the legislation mentions as co-official languages Spanish and English spoken «in the manner of the islands» (Congreso de Colombia, 1993). The Act 1381 of 2010 on Native Languages goes even further: It safeguards the programs which deal

\footnotetext{
5. The influence of Jamaican immigration in the formation of San Andrés-Providence CE is unquestionable and the cultural influence prevails, but there is no Jamaican community either on San Andrés or on Providence Islands. Besides, in spite of the survival of some French surnames, such as Pomare $(s)(<$ Pomaire) and Fiquaire ( $<$ Fiquaire), there is no permanent presence of Haitian/other French Creole on the archipielago.

6. Different sources give distinct years for the beginning of colonization. San Andrés, then called Henrietta, was abandoned as early as 1632 for the lack of sweet water reservoirs.
} 
The Making of Languages and New Literacies: San Andrés-Providence Creole with a View on Jamaican and Haitian with the preservation and diffusion of native languages at national, regional, and local level, as well as their use, including the use of anthro- and toponyms (Ministerio de Cultura, 2010). These legislative measures allow for a certain degree of both territorial and linguistic self-determination, nevertheless so far not made use of to their full potential. What is more, the sociolinguistic situation is in constant flux and there is cyclicity, too: For a long time, one step forward meant two or three steps backwards. This has changed with a reinvigorating boost in cultural and language activism (see below).

\subsection{Evolution of and Present-Day Sociolinguistic Situation of San Andrés and Providence}

Between 1946 and 1956, the use of English as a medium of instruction in public and private schools, respectively, was prohibited (Guevara, 2007). This would today be considered a violation of Linguistic Human Rights, especially when considering that certain schools, for instance the Baptist schools, had continued to use English despite the Hispanization campaign initiated earlier. The burning of Bibles took place in the same period. On the other hand, the absence of Standard English (henceforward StE) from the linguistic repertoire of the community during most of the 20th century may have led to recreolization and a favorable evaluation of Creole (Chaves, 1990, pp. 23-24).

In that sense, Colombian ethno-education legislation dates from 1978 and in 1980 the Interministerial Committee for the Incorporation of the islands into the National Integration Plan recommends the preservation of bilingualism in the archipelago. The Colombian laws dealing with linguistic issues of 1993 and 2010 were already mentioned in the previous section, as well as the fact that their effective implementation has been slow and efforts have suffered from discontinuity, especially in education. The trilingual project of 1999, run by the Baptist churches, the Christian University of San Andres, Providence and Santa Catalina, and the Summer Institute of Linguistics (SIL) shrank already before it ended in 2004. A ten-month teacher training program in 2006 run by two educators of San Andrés had little impact because of its lack of funding, among other things. Similar smallscale efforts have been made over the last years, e.g., a 2014-2015 Creole project for high school students and teachers funded by the Ministry of Education in Bogotá. Recent (2000s-) efforts by the same ministry to (re) introduce StE into the linguistic repertoires of all the inhabitants of the archipelago irrespective of their ethnolinguistic background have at the same time heightened language endangerment through the presence of the lexifier language.

In the case of San Andrés-Providence CE, estimates of up to 20,000 speakers have been cited whereas (Eberhard et al., 2020) gave the 1981 SIL figure of 12,000. Given the erosion of the speech community due to language shift, this may be quite close to the truth. Interethnic marriages, often blamed, are not the only reason

for the language not having been passed on inter-generationally. And yet Eberhard et al. (2020) classified the language as level 6a «Vigorous» on the Expanded Graded Intergenerational Disruption Scale (EGIDS) (Lewis \& Simons, 2010). On the other hand, despite the discontinuity of efforts to promote the language — which could 
The Making of Languages and New Literacies: San Andrés-Providence Creole with a View on Jamaican and Haitian be observed up to the very recent past_-, it can be actually stated that since these exist and are starting to gain momentum, the traditional diglossia as initially described by Ferguson (1959) is indeed leaking.

As far as the traditional media (local newspapers, radio, television) are concerned, a mostly qualitative survey over the time period 1999-2015 revealed that the situation for San Andrés-Providence CE clearly deteriorated with time. Just as in real life where many speakers — counting out language activists, of course - did not make a neat distinction between $\mathrm{CE}$ and $\mathrm{StE}$, at the turn of the millennium the whole range of English-lexifier variants would be employed on radio and television. Broadcasting time was drastically reduced from 2-3 hours per day on radio and a few hours, mainly on weekends, for local TV programming. Already in 2008, radio air time in StE, not CE, was the near-monopoly of two Christian radio stations — Christian Radio 92.5 FM, Good News 102.5 FM-, and broadcasting time for local TV productions had been reduced to a minimum, featuring creolized English at best. But the tide is turning in the audiovisual media as well: In 2017, the first full length motion picture entirely acted in San Andrés-Providence CE, «Bad Lucky Goat», was shot on Providence Island. However, the little CE/ StE there was in the newspapers, which now are essentially read as web versions, has disappeared. ${ }^{7}$

Native speakers continue to profess a high amount of loyalty towards the British and their language and, by default, to the English language in general, as opposed to the traditional reluctance to acknowledge a Creole/ African and not only English heritage — $c f$. Freeland (2004, pp. 111, 117), on the closely related and culturally very similar Nicaraguan CE community-. This is now changing. However, it is the stigmatization all creole languages suffer even among their speakers which explains not only why the opportunities for the officialization and standardization of the CE granted by the legislation mentioned above have not been made use of to their full potential — so far_-, but also why many speakers still see «Broken» English as part of English, not as a separate language. At the same time, there is awareness of $\mathrm{StE}$ or registers close to it being appropriate in certain contexts, $\mathrm{CE}$ in others, corresponding to the overt vs. covert prestige issue and leading to seemingly ambivalent attitudes and linguistic insecurity. At times, this linguistic insecurity is resolved by resorting to Spanish when speaking, for instance, to persons not belonging to the immediate community.

The fluidity or actually impossibility of drawing a border between $\mathrm{CE}$ and $\mathrm{StE}$ is not restricted to the sociolinguistic dimension of language use, but actually the entire language system to the effect that delimiting geographic, insular varieties may be misleading: There are different lects on both islands. In fact, it is possible to speak of a continuum, which spans from the most basilectal, mostly San Andresan varieties, over fairly mesolectal, specifically the closely related Nicaraguan varieties — which are not treated here - , to the most acrolectal ones, to be found frequently, but not exclusively, on Providence. Thence the term «San Andrés-Providence CE» actually seems justified (Bartens, 2009).

Overall Spanish, the dominant and sole official language during most of the 20th century, is resented especially by language and cultural activists, but has also managed to gain a certain amount of prestige, especially among women, as opposed to men on both islands (Flórez, 2006). Over the past few years, increased pride in the Creole

7. $\quad$ Five years after the latest fieldwork done on San Andrés in 2015, a realistic appraisal of air time on television and radio needs assessment in situ. 
The Making of Languages and New Literacies: San Andrés-Providence Creole with a View on Jamaican and Haitian language and culture — as well as the African roots — has become manifest through activities such as Emancipation Week festivities - celebrated throughout the Caribbean —, the Green Moon Festival, and the use of Creole in the social media, e.g., FB, which is addressed in the following section.

\subsection{Language Use on Facebook}

As stated above, FB and especially open FB groups constitute easily accessible material for studying language use, emergent norms, and ideologies. As an example of asynchronous communication, it provides a relatively safe space to practice the language in writing, which it is argued as paramount to the constitution of language in the present-day world. Obviously, negative comments and even cyberbullying exist in the social media, but it is different from face-to-face communication and not that likely to occur in FB groups which specifically aim at the promotion of minority languages. For the redefinition of the relationship between standard and non-standard varieties — such as the vision presented by Ferguson (1959), which considers, e.g., Haitian and Haitian Creole H and L varieties of the same language, is very much outdated - it is fundamental to bear in mind that participation in online social networks can play a fundamental role in language development (Duane, 2018; Abu-Irmies \& A1Khanji, 2019).

As far as San Andrés-Providence CE is concerned, until recently the language was not used very actively in an archipelago-specific group dealing with or functioning in the language. ${ }^{8}$ For example, most publications in the group «Raizal Cultural Heritage» are in Spanish. Nevertheless, the group «My grandma use to say», which has existed at least since 2015 and its main goal, which is not explicitly stated in a group description, is to collect sayings and proverbs from the islands. The group activity has seen an upsurge during spring-summer 2020. Most of its posts are indeed sayings and proverbs, but also humorous utterances; such as a post of July $27,2020:^{9}$

1. Grany we yo guain? Schriet tu jel ef a no chray fi siev mi suol. Granny where 2SG go.GER straight to hell if 1SG NEG try COMP save 1sG.POss soul «Granny, where are you going? Straight to hell if I don’t try to save my soul.»

Individual persons have been using more and more Creole in their posts and comments for at least the past few years, e.g.:

8. The categories relevant for the analysis were «content» and «language choice» (see section 1).

9. Permission to use examples 1 and 2 was secured from the respective authors. On July 27, 2020, the group «My grandma use to say» had one administrator and 1,961 members. 
2. Unu luk ova gud.' (comment on a photo, 08-01-2017)

2PL look over good

«You look extremely good.»

The Figure 1 reproduces an invitation to the 2016 Emancipation Day March posted on FB, in August 2016. The text reads in English translation: «Happy Emancipation Day! Raizal People! The conch shell has been blown. Come to the big march today, we are starting at 3:30 p.m. at the Central Baptist Church.».

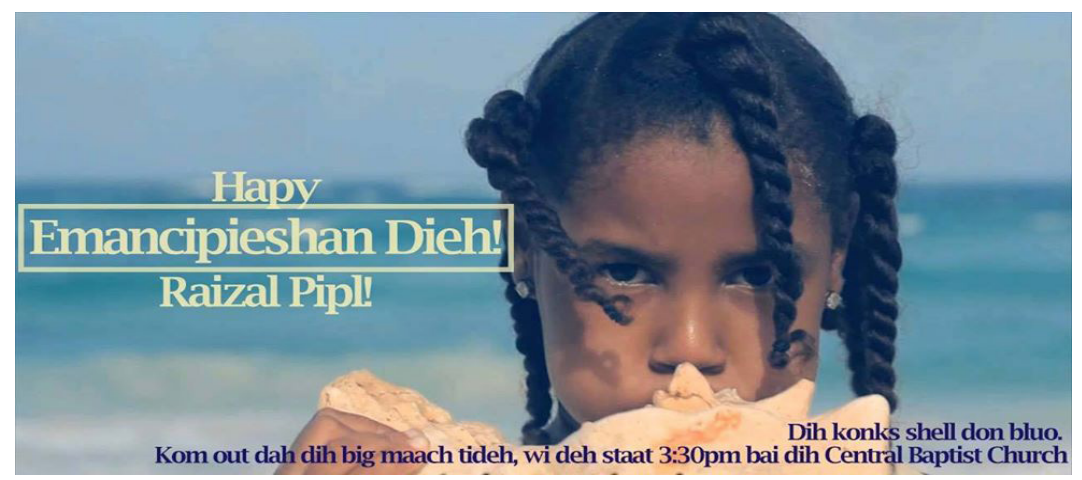

Figure 1. Invitation to the 2016 Emancipation Day March

It is likely that this trend will spread further on FB and other social networks. However, for the time being, it does not seem to affect traditional media, where the use of San Andrés-Providence CE is receding (see section 3.2.).

Three FB groups focusing on the promotion of its respective creoles serve as a point of comparison. For instance, the group «Jamaican National Dictionary» aims to compilate a web-based, multimedia dictionary in Jamaican Creole (Patwa or Jumiekan), Jamaican English, and other language varieties used in Jamaica. Its membership has been moderately growing since its creation (03-14-2016: 1,606; 08-04-2016: 1,791; 11-11-2017: 2,723; 08-04-2018: 2,823; 12-30-2018: 2,896; 01-12-2020: 3,059; 07-27-2020: 4,179). In practice, however, the inclusion of all Creole dialects is discussed, which is, nevertheless, understandable, given the highly specific goal of the group. The group has five administrators and two moderators who keep the discussions to languagerelated topics. ${ }^{10}$ With regard to this and the other two groups, it has to be noted that it is very difficult to make a quantitative study, as some posts are no longer visible, since they may have been removed either by the author or the administrator. For example, a post on February 17, 2016, reads «Did» and has to be followed to an original May 23, 2014 post, where a member asks:

$\overline{10 . \quad \text { Personal }}$ communication with Joseph T. Farquharson, Aug. 2016. In other groups, publicity for cultural events and the like is very common. 
The Making of Languages and New Literacies: San Andrés-Providence Creole with a View on Jamaican and Haitian 3. « If JC is ever standardised, which past tense form will triumph? did, en, ben, or wen? »

Therefore, the approach to theses FB groups could only be qualitative.

As in any group, there are some very active members who post regularly and most posts provoke several comments, which can be interpreted as an expression of interest in this collective endeavor. If successful, it would constitute primarily an example of grassroots corpus planning at its best, but also status planning for promoting Jumiekan. Note, however, that most posts are in English with Jumiekan. ${ }^{11}$ Is this an expression of the often mentioned and doubtlessly prevalent bilingual identity of many Jamaicans — while 46.4\% of Jamaicans are bilingual, 17.1\% use only English and 36.5\% use only Jumiekan (Farquharson, 2013) — or is it an expression of baby steps in status planning?

After all, writing in Jumiekan —as well as the option of using it in the educational system — continues to be a highly contested topic, even in this group and despite the fact that a wealth of materials has been developed in the recent past — since 2002 — , above all by the Jamaican Language Unit of the University of the West Indies (JLU). ${ }^{12}$ In this sense, too, this group and the activity in it constitutes an important case of the making or, considering the relatively advanced status of the development of Jumiekan vis-à-vis many other creoles spoken in the region, consolidation of a language and creation of new literacies where the traditional medium of printed material has not quite caught on. At least since the 19th century has Jumiekan been used to mark characters and help create setting in literature. There is a tradition of writing poetry in it, but the tendency is still to use it for comic purposes, i.e., the use is folklorizing (Farquharson, 2013; Lalla \& D'Costa, 1990). A petition to make Jamaican an official language alongside English launched in late 2019 did not meet its goal of the 15,000 signatures required to force the Government to issue a statement on the issue. ${ }^{13}$

Over the period, there have been studies on the first Haitian Creole group between 2016 and 2020, which was initially called «Kreyòl, The Official Language Of Haïti, Creating Haitian Citizens For Haïti»; then «Ayisyen/ Kreyòl, The Language Of Haïti, Creating Haitian Citizens For Haïti», intending to enhance the likelihood of being found by googling, by interviewing people who were familiarized with the official Haitian orthography, and by looking for content specifically related to this language; and finally «Kreyòl, The Language Of Hayti, Creating Haytian Citizens For Hayti», which removes the identification with Haiti at the beginning of the name, but it is still in line with the official orthography for the language. Targeting specifically Haitians, it is also manifest in the partly distinct descriptions of the group in both English and Haitian. The latter one is also more elaborate and stresses, for instance, the apoliticalness of the group. ${ }^{14}$ It is currently managed by two administrators and its membership is very low (03-14-2016: 506, 08-04-2016: 505, 11-11-2017: 555, 08-04-2018: 545; 12-30-2018:

$\overline{11 . \quad \text { Because }}$ it is a qualitative study, the impressionistic attribute «most» is used on this paper.

12. For more, visit https://www.mona.uwi.edu/dllp/jlu/

13. For more, visit https://opm.gov.jm/participate/jamaica-house-petition/sign-petition/?pet=100

14. For more, visit https:/www.facebook.com/groups/340523019371011/about/ 
The Making of Languages and New Literacies: San Andrés-Providence Creole with a View on Jamaican and Haitian 543; 01-12-2020: 403; 07-27-2020: 408), considering that the number of speakers of Haitian is at least of 11 million including the diaspora (Fattier, 2013). It is also striking that, unlike in other groups, the membership is not rising but falling. Although there is use of both Kreyòl and multimedia, there has been a relatively scarce activity in the recent past — only two posts in December 2019 - which suggests that users other than the most active members have moved to different groups or even personal pages. Therefore, the group does not really reach out to the community as a forum to practice and consolidate the language prestige of Kreyòl and its literacy.

The closed group «Ti Tonel Lekol poun li Ekri Kreyol» («A little hut for reading and writing [Haitian] Creole»), on the other hand, has quite a number of members (03-14-2016: 3,771; 08-04-2016: 11,111; 11-11-2017: 13,399; 08-04-2018: 13,572; 12-30-2018: 13,504; 01-12-2020: 10,074; 07-27-2020: 10,044). However, it is possible to register a decrease in memberships as well, due to that its slogan Aba lanng franse, aba lanng angle, nan gwoup sa $a$ («Down with French, down with English in this group») appeals to a certain public tired of both Franco and Anglophone cultural neocolonialism. The description of the group, though, is quite reconciliatory: Pap bliye mezanmi anba titonel la se kreyol net ale wi... («Let's not forget, my friends, that under our little hut it's Kreyòl all the way...»). ${ }^{15}$ There are frequently several posts a day, especially by a poet and one of the four administrators of the group. There is also cultural content — such as paintings, photos, cultural news, cuisine, etc.—, which basically reaches out to an already quite considerable group of people interested in practicing Kreyòl literacy. If participation by members different than the most active ones in such groups were more frequent, the impact would, of course, be more substantial.

An interesting topic would be to see to what extent official Haitian orthography is being implemented. On the other hand, writing and reading Kreyòl is an achievement per se: The first hurdle is to actively engage in literacy practices. Heterography can be conceived of as a first step (Blommaert, 2008). In this sense, computermediated communication (CMC) nearly inevitably makes use of specific conventions, which cannot be ignored in a linguistic appraisal of the discussions in these groups, such as the following comment on a post:

4. Bnju fcbk mp profite di tt mun [...] svp ekrim prive. (10-26-2017)

Bonjou facebook $m$ ap profite ${ }^{16}$ di tout mun $[\ldots]$ souple ekri-m prive good-day Facebook 1sG PROG take.advantage say whole world [...] please write-me in private «Hello Facebook, I'm taking advantage of the opportunity to tell everybody [...] please inbox me.»

Haitian Kreyòl has an even longer tradition than Jumiekan as a written language: Kreyòl was first used for both official and literary purposes in the late 18th century, although widespread use in writing did not occur until about 200 years later. The relatively little that was written in the meantime was written in an etymologizing

15. Translation kindly provided by Michel DeGraff, March 2016.

16. In the official orthography, pwofite. This writer clearly speaks an r-full variety. 
The Making of Languages and New Literacies: San Andrés-Providence Creole with a View on Jamaican and Haitian script. Orthography development leading to the adoption of the fairly phonematic actual official orthography in 1979 started around 1940 (Schieffelin \& Charlier Doucet, 1994). Haitian is probably the most advanced creole language in the long process of standardization (Fattier, 2013), yet just over 60\% of Haitians living in Haiti are literate. Thence, its use in social media, e.g., on FB, could constitute a relatively important venue for practicing literacy. Note, however, that only $12 \%$ of the population of Haiti has internet access (CIA, 2019). This situation is very different in Jamaica and San Andrés and Providence Islands, where internet networks are widespread among the population.

Finally, it has to be born in mind that when checking FB groups accounts, the user is searching for communities of practice which transcend national borders and are, at least in part, even unimagined pace (Anderson, 1983), drawing in less competent or so-called peripheral speakers (Labov, 1972). Participants in FB groups exchange ideas with members of other groups as well about, for example, how to write certain graphemes on distinct keyboards, just as language promoters would do in face-to-face interaction. This is illustrated in a post from «Palé Kwéyòl Donminik», a group promoting Dominican Creole French, in «Ti Tonel...» reproduced in Figure 2:

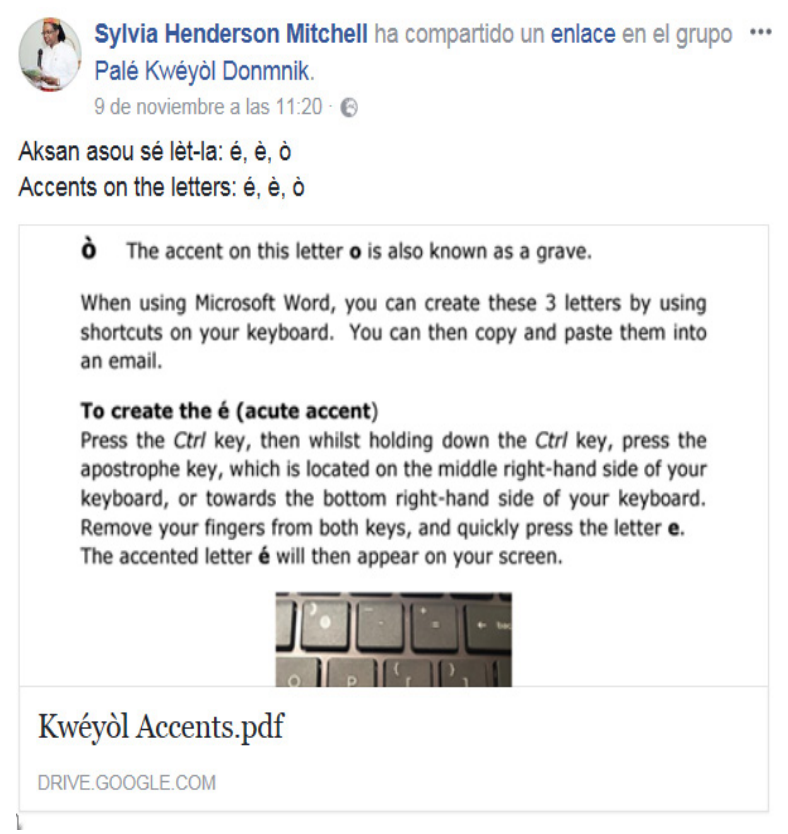

Figure 2. A post from Palé Kwéyòl Donminik reposted in Ti Tonel Lekol poun Ii Ekri Kreyol, November 9, 2017

\subsection{San Andrés Linguistic Landscapes}

As mentioned in section 3.2., the use of San Andrés-Providence CE is not yet spreading from the social media to the traditional one. However, the increased pride in Creole language and culture is visible not only in the linguistic landscape of cyberspace ( $c f$. Figure 1), but also in the tangible land- and cityscape of San Andrés. Creole language signs for diverse purposes are placed side by side with Spanish and English ones — the latter mainly for 
The Making of Languages and New Literacies: San Andrés-Providence Creole with a View on Jamaican and Haitian tourists - or exclusively where the public is assumed to be mainly Creole-speaking. Given the long tradition of minorization, having San Andrés-Providence CE signs at all, even in a subordinate position — cf. Wang (2018), on Enshi Fangyan signs - as the 2015 election campaign poster in Figure 3 -located off the road and outside the urban center - is eventually leading to coexistence with Spanish as in Figure 4 - a poster in Creole on the notice board of the Secretariat of Education exhorting parents to send their children to school; the poster is among other posters in Spanish with the same content - or exclusive use of Creole as in Figure 5 - a sign forbidding eating inside the library of the First Baptist Church School; it is important to add that a lot of the signage around the school is makeshift_- But the first steps have been taken to claim ownership of not only the language and the culture, but the physical space as well. Whereas the sign in Figure 3 is likely to be directed to Creole-speaking people, the sign in Figure 5 has an educational message for the students of such school whose first language is not only San Andrés-Providence CE, so all similar signs inside of the library of the school — where Creole is promoted most vigorously on San Andrés - are written in that language.

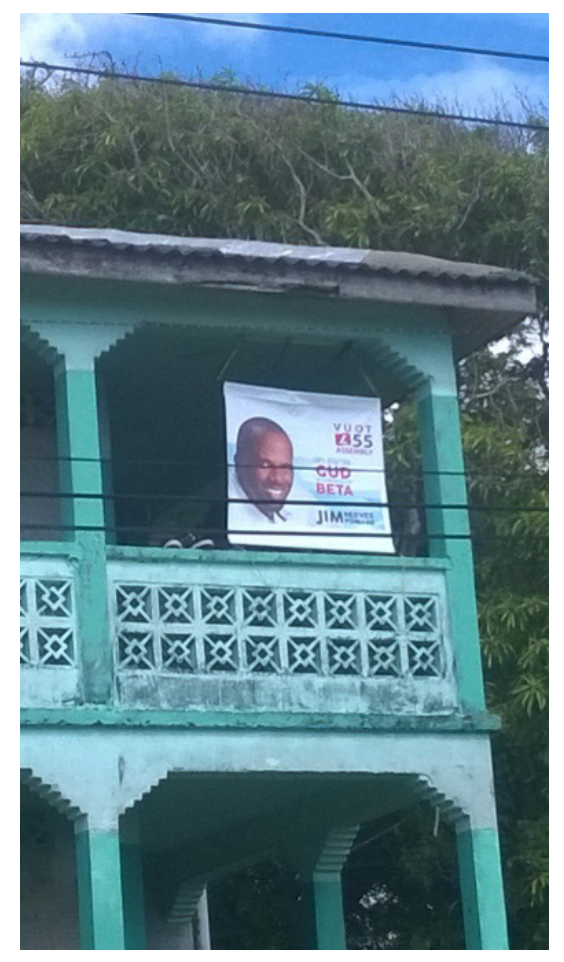

Figure 3. 2015 election campaign poster from rural area in San Andrés in Creole. Angela Bartens. 


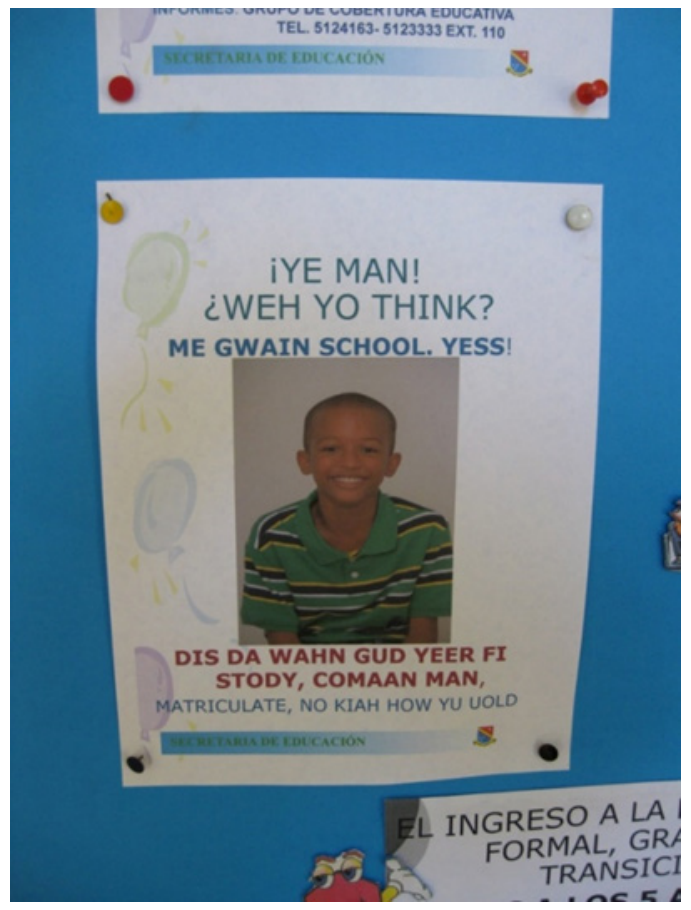

Figure 4. Poster on the notice board of the Secretariat of Education of San Andrés, summoning parents to enroll their children in school, August 2015. Angela Bartens.

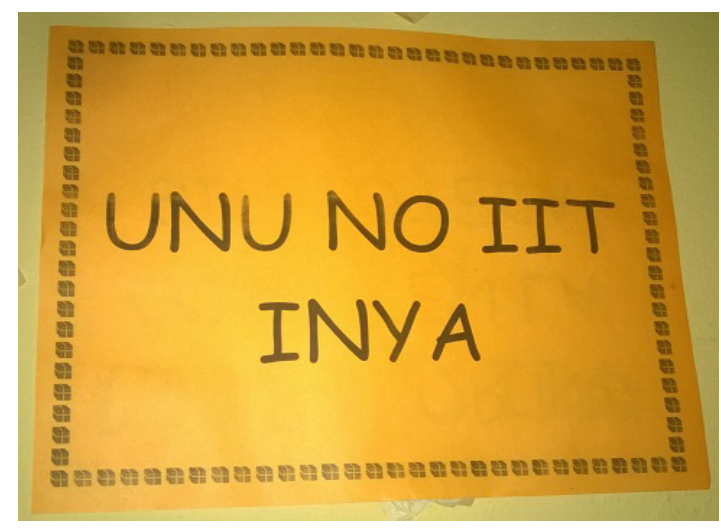

Figure 5. Sign in the library of the First Baptist School, San Andrés, 2015. Angela Bartens.

\section{Discussion and Conclusions}

Metalinguistic discourses help construct, reproduce, and modify linguistic ideologies (Verschueren, 2012; MarMolinero, 2008; Makoni \& Pennycook, 2005), including the conscience regarding the existence of a language. In this process, all media play a fundamental role, but the new media and technologies are used more often as online metalinguistic communities become major players in Language Policy and Planning (LPP) and sociolinguistic 
The Making of Languages and New Literacies: San Andrés-Providence Creole with a View on Jamaican and Haitian change (Duane, 2018).

On the traditional scale from orality to literacy (Goody, 1968; Ong, 1982; Thaler, 2003; Montes-Alcalá, 2016), new technologies like text messaging, chats, Twitter or FB enable Creole users — and other minority and minorized languages users - to enter, so to speak, through the back door into the domain of literacy, which is very fundamental for a linguistic variety to be considered a language in the sense of Western-dominated linguistic ideologies, which preconize standard orthographies (Lüpke, 2018) in the long run. As a result, it is simply not possible to ignore the importance of writing.

Especially the world's most peripheral and endangered languages benefit from the opportunities offered by the internet and new technologies (Eisenlohr, 2004; Cormack, 2007). As argued above, asynchronous communication provides a safe space to practice the language — in writing — as well as language-ideological work (Duane, 2018). A gradual decolonization or dismantling of the traditional power relationships between $\mathrm{H}$ and L languages/ varieties (Ferguson, 1959) may lead to the democratization of former elite practices (Mair, 2019) as well as a cumulative effect of adoption of innovations of both structure and attitudes (Rogers, 2003).

New communities of practice are created (Eckert \& McConnell-Ginet, 1992) where so-called peripheral or less competent speakers (Labov, 1972) can be integrated and crossing and the performing of situational ethnicities becomes possible (Keefe \& Padilla, 1987). Nevertheless, some regulation in language development is obviously needed (Eira \& Stebbins, 2008). Indeed, cyberspace has developed a sociolinguistic order of its own —cf. Mair (2019), on Jamaican Standard English vs. Jamaican Creole and Nigerian Standard English vs. Naija- . What is stigmatized on the ground actually becomes prestigious in cyberspace. Eventually, this may reflect on offline communication. FB groups, among other venues, thence can play a crucial role in language revitalization and development, including new literacies, and the making of languages as appears to be the case of the communities presented in this study.

The aim of this paper was to examine language making and new literacies in creole languages with a focus on San Andrés-Providence CE. Jamaican CE and Haitian Creole were taken as points of comparison as far as the consolidation of languagehood and graphicization of creoles is concerned. Posts from FB groups gathered between February 2016 and July 2020 as the main source of data were complemented by 2015 data on San Andrés linguistic landscapes. The categories for which the data was analyzed qualitatively were «content» and «language choice». The main finding is that, due to a favorable change in language attitudes both locally and globally, San Andrés-Providence CE is entering into the domain of writing.

Multiple paths of further study suggest themselves, both comparative and focused on a specific creole. For example, it could be studied to what extent users observe ratified orthographies in a given type of social media network. An issue of utmost importance especially in settings of sociohistorical and political conflict, which has to be taken into account when discussing language making, new literacies, and the access to them, is the one of language ownership: Who is entitled to learn, revitalize, develop and cultivate a language? This question clearly needs to be addressed in the future as language use and new literacies appear in the future. 
The Making of Languages and New Literacies: San Andrés-Providence Creole with a View on Jamaican and Haitian Bibliographical References

1. Abu-Irmies, A. \& Al-Khanji, R. R. (2019). The Role of Social Media in Maintaining Minority Languages: A Case Study of Chechen Language in Jordan. International Journal of Linguistics, 11(1), 62-75.

2. Anderson, B. (1983). Imagined Communities: Reflections on the Origin and Spread of Nationalism. London: Verso.

3. Baker, P. (1990). Off Target? Journal of Pidgin and Creole Languages, 5(1), 107-119.

4. Bartens, A. (2001). The Rocky Road to Education in Creole. In M. Fernández (Ed.), Shedding Light on the Chabacano Language. Estudios de Sociolingüística, 2(2), 27-56.

5. Bartens, A. (2009). A Comparison of the English-Based Creoles of Nicaragua and San Andrés and Old Providence. Neuphilologische Mitteilungen, III: CX, 299-318.

6. Bartens, A. (2013a). San Andres Creole English. In S. Michaelis, P. Maurer, M. Huber \& M. Haspelmath (Eds.), The Survey of Pidgin \& Creole Languages. Vol. 1. English-Based and Dutch-Based Languages (pp. 101-114). Oxford: Oxford University Press.

7. Bartens, A. (2013b). Nicaraguan Creole English. In S. Michaelis, P. Maurer, M. Huber \& M. Haspelmath (Eds.), The Survey of Pidgin \& Creole Languages. Vol. 1. English-Based and Dutch-Based Languages (pp. 115126). Oxford: Oxford University Press.

8. Bartens, A. (2013c). Creole Languages. In P. Bakker \& Y. Matras (Eds.), Contact Languages. A Comprehensive Guide. Language Contact and Bilingualism, 6, (pp. 65-158). Boston/Berlin: Mouton de Gruyter.

9. Bartens, A. (2018). Language Ideologies in the San Andrés (and Old Providence) Raizal Community on the Way to Democracy. Neuphilologische Mitteilungen, II CXIX, 393-418.

10. Blommaert, J. (2008). Grassroots Literacy: Writing, Identity and Voice in Central Africa. London: Routledge.

11. Chaudenson, R. (1992). Des îles, des hommes, des langues. Paris : L'Harmattan.

12. CIA (2019). Haiti. In The World Factbook. https://www.cia.gov/library/publications/the-world-factbook/geos/ ha.html

13. Clemente, B. I. (1991). Educación, política educativa y conflicto político-cultural en San Andrés y Providencia/ Providence (1886-1980). Bogotá: Fundación para la Promoción de la Investigación y la Tecnología.

14. Cormack, M. (2007). The Media and Language Maintenance. In M. Cormack \& N. Hourigan (Eds.), Minority Language Media: Concepts, Critiques and Case Studies (pp. 52-68). Clevedon: Multilingual Matters.

15. Crystal, D. (2000). Language Death. USA: Cambridge University Press.

16. Duane, L. (2018). Salty Politics and Linguistics in the Balearic Islands: Tracing a Non-Standard Iconization in Metalinguistic Facebook Communities. In C. Weth \& K. Juffermans (Eds.), The Tyranny of Writing. Ideologies of the Written Word (pp. 197-212). London: Bloomsbury.

17. Eckert, P. \& McConnell-Ginet, S. (1992). Think Practically and Look Locally: Language and Gender as Community-Based Practice. Annual Review of Anthropology, 21, 461-490. 
The Making of Languages and New Literacies: San Andrés-Providence Creole with a View on Jamaican and Haitian 18. Eberhard, D. M., Simons, G. F., \& Fennig, C. D. (Eds.) (2020). Ethnologue: Languages of the World. 23rd edition. Dallas: SIL International. http://www.ethnologue.com

19. Edwards, J. (1968). Social Linguistics on San Andres and Providence Islands. Paper presented at the American Anthropological Society Convention, Seattle, November 1968.

20. Eira, C. \& Stebbins, T. (2008). Authenticities and Lineages: Revisiting Concepts of Continuity and Change in Language. International Journal of the Sociology of Language, 189, 1-30.

21. Eisenlohr, P. (2004). Language Revitalization and New Technologies: Cultures of Electronic Mediation and the Refiguring of Communities. Annual Review of Anthropology, 33, 21-45.

22. Farquharson, J. T. (2013). Jamaican. In S. Michaelis, P. Maurer, M. Huber \& M. Haspelmath (Eds.), The Survey of Pidgin and Creole Languages. Vol. 1. English-Based and Dutch-Based Languages (pp. 81-91). Oxford: Oxford University Press. https://apics-online.info/surveys/8

23. Fattier, D. (2013). Haitian Creole. In S. Michaelis, P. Maurer, M. Huber \& M. Haspelmath (Eds.), The Survey of Pidgin and Creole Languages. Vol. 2. Portuguese-Based, Spanish-Based, and French-Based Languages (pp. 195-204). Oxford: Oxford University Press. https://apics-online.info/surveys/49

24. Ferguson, C. (1959). Diglossia. Word, 15(2), 325-340.

25. Fishman, J. A. (1991). Reversing Language Shift: Theory and Practice of Assistance to Threatened Languages. 26. Flórez, S. (2006). A Study of Language Attitudes in Two Creole-Speaking Islands: San Andres and Providence (Colombia). Íkala, Revista de Lenguaje y Cultura, 11(17), 119-147.

27. Frank, D. B. (2007). We Don't Speak a Real Language: Creoles as Misunderstood and Endangered Languages. Paper presented at the Symposium on Endangered Languages in College Park, MD, sponsored by the National Museum of Language, March 25, 2007. http://www.saintluciancreole.dbfrank.net/workpapers/creoles_as_ misunderstood.pdf

28. Freeland, J. (1993). «IAm a Creole, so I speak English»: Cultural Ambiguity and the English/Spanish BilingualBicultural Programme of Nicaragua's Atlantic Coast. In D. Graddol, L. Thompson \& M. Byram (Eds.), Language and Culture: Papers from the Annual Meeting of the British Association of Applied Linguistics, September 1991 (pp. 70-83). Clevedon: Multilingual Matters.

29. Freeland, J. (2004). Linguistic Rights and Language Survival in a Creole Space: Dilemmas of Nicaragua's Caribbean Coast Creoles. In J. Freeland \& D. Patrick (Eds.), Language Rights and Language Survival: A Sociolinguistic and Sociocultural Approach (pp. 103-138). Manchester: St. Jerome Publishing.

30. Goody, J. (1968). Literacy in Traditional Societies. Cambridge: Cambridge University Press.

31. Gordon, E. T. (1998). Disparate Diasporas. Identity and Politics in an African Nicaraguan Community. Austin, TX: Institute of Latin American Studies, University of Texas Press.

32. Grimm, J.(1864). Kleinere Schriften 1: Reden und Abhandlungen. Berlin: Ferd. Dümmlers Verlagsbuchhandlung. 33. Guevara, Natalia (2007). San Andrés Isla, Memorias de la colombianización y Reparaciones. In C. MosqueraRosero Labbé \& L. C. Barcelos (Eds.), Afro-reparaciones: Memorias de la Esclavitud y Justicia Reparativa para 
The Making of Languages and New Literacies: San Andrés-Providence Creole with a View on Jamaican and Haitian negros, afrocolombianos y raizales (pp. 295-318). Bogotá: Universidad Nacional de Colombia.

34. Holm, J. A. (1978). The English Creole of Nicaragua's Miskito Coast: It's Sociolinguistic History and a Comparative Study of Its Lexicon and Syntax. PhD dissertation. University of London, University College.

35. Holm, J. (1983). Nicaragua's Miskito Coast Creole English. In J. Holm (Ed.), Central American English. Varieties of English Around the World. Vol. 2. T2 (pp. 95-130). Heidelberg: Julius Groos.

36. Holm, J. (1986). The Spread of English in the Caribbean Area. In M. Görlach \& J. Holm (Eds.), Focus on the Caribbean, Varieties of English Around the World G8 (pp. 1-22). Amsterdam: John Benjamins.

37. Hüning, M. \& Krämer, P. (2018). Negotiating Standards between Suriname and the Netherlands. Paper presented at the International Conference for Postcolonial Linguistics, Zurich, June 2018.

38. Keefe, S. E. \& Padilla, A. (1987). Chicano ethnicity. Albuquerque, NM: University of New Mexico Press. 39. Koskinen, A. (2010). Kriol in Caribbean Nicaragua Schools. In B. Migge, I. Léglise \& A. Bartens (Eds.), Creoles in Education: An Appraisal of Current Programs and Projects (pp. 133-165). Amsterdam \& Philadelphia: John Benjamins.

40. Labov, W. (1972). Sociolinguistic Patterns. Philadelphia, PA: University of Philadelphia Press.

41. Lalla, B. \& D’Costa, J. (1990). Language in Exile: Three Hundred Years of the English Language in Jamaica. Tuscaloosa: University of Alabama Press.

42. Landry, R. \& Bourhis, R.Y. (1997). Linguistic Landscape and Ethnolinguistic Vitality: An Empirical Study. Journal of Language and Social Psychology, 16(1), 23-49.

43. Lehikoinen, L. \& Kiuru, S. (1991). Kirjasuomen kehitys. Helsinki: Helsingin yliopiston suomen kielen laitos. 44. Lewis, M. P. \& Simons, G. F. (2010). Assessing Endangerment: Expanding Fishman's GIDS. Revue Roumaine de Linguistique, 55(2), 103-120.

45. Lüpke, F. (2018). Escaping the Tyranny of Writing: West African Regimes of Writing as a Model for Multilingual Literacy In C. Weth \& K. Juffermans (Eds.), The Tyranny of Writing. Ideologies of the Written Word (pp. 129-147). London: Bloomsbury.

46. Mair, C. (2019). World Englishes in Cyberspace. In D. Schreier, M. Hundt \& E. W. Schneider (Eds.), The Cambridge Handbook of World Englishes (pp. 360-383). Cambridge: Cambridge University Press.

47. Makoni, S. \& Pennycook, A. (2005). Disinventing and (Re)Constituting Languages. Critical Inquiry in Language Studies, 2(3), 137-156.

48. McArthur, T. B. (1998). The English Languages. Cambridge: Cambridge University Press.

49. Montes-Alcalá, C. (2016). iSwitch: Spanish-English Mixing in Computer-Mediated Communication. Journal of Language Contact, 9, 23-48.

50. O’Flynn de Chaves, C. (1992). Tiempo, aspecto y modalidad en el criollo Sanandresano (M.A. thesis.) Bogotá: Universidad de los Andes/Colciencias.

51. Ong, W. J. (1982). Orality and Literacy: The Technologizing of the Word. London/New York: Routledge. 52. Pasanen, M. A. (2004). «I'm a Creole, so I speak English»-«I'm an Indian, but speak Creole»: Kreolin 
The Making of Languages and New Literacies: San Andrés-Providence Creole with a View on Jamaican and Haitian konstituoiminen Nicaraguan Atlantin rannikolla (M.A. thesis). Universtiy of Helsinki.

53. Petersen, W. G. (2001). The Province of Providence. San Andrés Island, Colombia: The Christian University of San Andrés, Providence and Kathleen Islands.

54. Rickford, J. R. (1985). Standard and Non-Standard Language. Attitudes in a Creole Continuum. In N. Wolfson \& J. E. Manes (Eds.), Language of Inequality (pp. 145-160). Berlin: Mouton.

55. Rogers, E. (2003). Diffusion of Innovation. New York: Free Press.

56. Schreier, M., Stamann, C., Janssen, M., Dahl, T. \& Whittal, A. (2019). Qualitative Content Analysis: Conceptualizations and Challenges in Research Practice - Introduction to the FQS Special Issue «Qualitative ContentAnalysis I». Forum Qualitative Social Research/Qualitative Sozialforschung, 20(3), Art. 38. https://searchproquest-com.ezproxy.utu.fi/publiccontent/docview/2330761178?accountid=14774\&pq-origsite=summon 57. Sorba, N. (2019). La polynomie: La construction démocratique d'une langue. Neuphilologische Mitteilungen, CXIX (II), 297-308.

58. Thaler, V. (2003). Chat-Kommunikation im Spannungsfeld zwischen Oralität und Literalität. Berlin: Verlag für Wissenschaft und Forschung.

59. van Dijk, Teun A. (2003). Ideología y discurso. Barcelona: Ariel.

60. Wang, X. (2018). Fangyan and The Linguistic Landscapes of Authenticity: Normativity and Innovativity of Writing in Globalizing China. In C. Weth \& K. Juffermans (Eds.), The Tyranny of Writing. Ideologies of the Written Word (pp. 165-182). London: Bloomsbury.

61. Wilson, P. (1973). Crab Antics. The Social Anthropology of English-Speaking Negro Societies of the Caribbean. New Haven, CT: Yale University Press.

62. Winer, L. (1990). Orthographic Standardization for Trinidad and Tobago: Linguistic and Sociopolitical Consideration and an English Creole Community. Language Problems and Language Planning, 14, $237-268$. 63. Zentella, A. C. (1997). Growing Up Bilingual. Malden, MA: Blackwell. 